\title{
0 uno e o múltiplo nos discursos barrocos do Padre Antônio Vieira
}

\author{
Josenildo Campos Brussio (UFMA)* \\ https://orcid.org/0000-0001-7721-9199
}

Daciléia Lima Ferreira (UFMA)**

https://orcid.org/0000-0003-3322-1291

\section{Resumo:}

Este artigo tem por objetivo refletir sobre o caráter uno e múltiplo nos discursos do Padre Antônio Vieira no Sermão da Primeira Dominga da Quaresma, proferido no Maranhão, no século XVII à luz da noção ideológica de sujeito de Mikhail Bakhthin, as noções do Imaginário de Gilbert Durand e Gaston Bachelard, as teorias sobre o Imaginário Social jesuítico do antropólogo e pesquisador Luiz Felipe Baêta Neves entre outros grandes teóricos. Os sermões de Vieira são conhecidos pela retórica barroca, mas, acima de tudo, pela riqueza, excentricidade e diversidade de sujeitos que ele consegue representar nas construções de seus discursos. Metodologicamente, analisaremos neste artigo apenas um sermão do Padre Antônio Vieira, escrito no Maranhão do século XVII, dada a extensão da obra do grande orador sacro da língua portuguesa, que escreveu mais de duzentos sermões ao longo de sua vida. Como resultado, mostraremos o caráter uno e múltiplo do Pe. Antônio Vieira a partir de algumas imagens complexas do jesuíta no Sermão da Primeira Dominga da Quaresma: a imagem do justiceiro, que converge com a imagem heroica do soberano mago e guerreiro na classificação isotópica das imagens de Gilbert Durand (1997).

Palavras-chave: Pe. Antônio Vieira. Discursos barrocos. Bakhtin.

\section{Abstract:}

\section{The one and the multiple in the baroque speeches of Padre Antônio Vieira}

This article aims to reflect on the one and multiple character in Padre Antônio Vieira's speeches in the Sermon of the First Dominga da Quaresma, given in Maranhão, in the 17th century in the light of Mikhail Bakhthin's ideological notion of "subject", the notions of Imaginary of Gilbert Durand

* Professor Adjunto do Curso de Licenciatura em Ciências Humanas/Sociologia da UFMA/Campus de São Bernardo. Doutor em Psicologia Social pela Universidade do Estado do Rio de Janeiro (2012).

Email: josenildobrussio@gmail.com

** Mestranda do Programa de Pós-Graduação em Cultura e Sociedade (PGCult), da Universidade Federal do Maranhão. Email: limadacileia@gmail.com 
and Gaston Bachelard, the theories about the Jesuit Social Imaginary of the anthropologist and researcher Luiz Felipe Baêta Neves, among other great theorists. Vieira's sermons are known for their Baroque rhetoric, but, above all, for the richness, eccentricity and diversity of subjects he manages to represent in the construction of his speeches. Methodologically, we will analyze in this article only a sermon by Padre Antônio Vieira, written in 17th century Maranhão, given the extent of the work of the great sacred speaker of the Portuguese language, who wrote more than two hundred sermons throughout his life. As a result, we will show the one and multiple character of Padre Antônio Vieira from one of his most complex images in the Sermon of the First Dominga da Lares: the image of the vigilante, which converges with the heroic image of the sovereign wizard and warrior in the isotopic classification from Gilbert Durand's images (1997).

Keywords: Padre Antônio Vieira. Speeches. Bakhtin.

\section{Introdução}

O Padre Antônio Vieira é considerado, por muitos pesquisadores, uma figura icônica do Barroco literário no Brasil do século XVII, visto por muitos como um dos grandes representantes da Companhia de Jesus.

De fato, a sua produção é vasta, na qual se destacam o clamor de seus sermões, as cartas e as profecias. Por essa razão, faremos uso somente de um sermão, neste artigo, para dialogarmos com concepções teóricas da Psicologia Social, mais especificamente, do Imaginário Social, na contemporaneidade. 0 sermão escolhido foi o Sermão de Santo Antônio, direcionado aos peixes (1654).

Feita esta seleção, interessa-nos, neste texto, apresentar as diferentes faces de Vieira presentes em seus diversos sujeitos (no sentido bakhtiniano) que eclodem circunstancialmente no Sermão da Primeira Dominga da Quaresma ou das Tentações (1653).

O crítico literário Alfredo Bosi (2001) observa que os jesuítas se utilizavam da alegoria como instrumento pedagógico no processo de catequização do aborígene. Percebemos, no Sermão da Primeira Dominga da Quaresma, que Vieira também se utiliza deste recurso para pregar aos fazendeiros do Maranhão na defesa dos índios.

Eloy Coelho Netto (1985) aponta os sermões mais importantes de Vieira no Maranhão, por seu conteúdo e contundência, assim os distribuindo:

[...] o "Sermão da Primeira Dominga da Quaresma" (1653) condena a escravidão indígena e apela para a consciência dos moradores; o "Sermão da Quinta Dominga da Quaresma" (1654) mostra que não há verdade no Maranhão, onde os moradores acusavam e afrontavam os jesuítas que defendiam os índios; o "Sermão de Santo Antônio" (1654) condena a corrupção no Maranhão, as lutas internas, além disso, repreende os moradores que por causa dos negócios do algodão perdiam a consciência cativando os índios; o "Sermão do Espírito Santo" (1657) define a pregação dos indígenas, revela as dificuldades a vencer, destaca a língua e a rudeza da gente, e reforça a glória do ofício de pregar a fé e salvar as almas (COELHO NETTO, 1985, p. 101).

José Honório Rodrigues (apud COELHO NETTO, 1985, p. 101) aponta estes três sermões como os mais importantes do orador sacro durante a sua passagem pelo Maranhão. Outro pesquisador, Jomar Mo- 
raes (1979), que presidiu a Academia Maranhense de Letras nos anos 90, também destaca aqueles três sermões como os mais significativos dentre os proferidos pelo jesuíta, no Estado.

Embora os três sermões acima também sejam destacáveis, este artigo tem por objetivo refletir sobre o caráter uno e múltiplo do discurso do Padre Antônio Vieira em um dos seus sermões proferidos no Maranhão no século XVII: o Sermão da Primeira Dominga da Quaresma (1653).

Os sermões de Vieira são conhecidos pela retórica barroca, mas, acima de tudo, pelos diversos sujeitos presentes nos diferentes sermões proferidos pelo Padre. Optamos pelo Maranhão em razão do recorte metodológico, dada a extensa obra do grande orador sacro da língua portuguesa ${ }^{1}$.

Para tanto, faremos, na primeira seção, uma exposição dessas diversas faces do Padre Antônio Vieira, sob uma perspectiva histórica de seus sermões, situando esse sujeito - homem, padre - em sua multiplicidade de atividades profissionais. Na segunda seção, apresentaremos este sujeito numa concepção dialógica bakhtiniana, principalmente, na percepção do olhar do sujeito Padre Antônio Vieira na construção de sermões. Na última seção, traçaremos uma análise desses múltiplos sujeitos e olhares a partir do Sermão da Primeira Dominga da Quaresma à luz da noção ideológica de sujeito de Mikhail Bakhtin, das noções do imaginário de Gilbert Durand e Gaston Bachelard e das teorias sobre o imaginário social jesuítico

1 O Padre Antônio Vieira escreveu mais de 200 sermões ao longo de carreira presbiteral. 0 missionário esteve no Maranhão entre os anos de 1653 e 1661. Sua presença nesta terra foi marcante quer nas mudanças que ocasionou na luta contra os colonos pela defesa dos índios, quer no processo de evangelização, que resultou na produção de dezessete sermões (MORAES, 1979). do antropólogo e pesquisador Luiz Felipe Baêta Neves entre outros grandes teóricos.

\section{As faces do Padre Antônio Vieira}

Ainda que relatássemos em poucas ou muitas linhas a história de vida do Padre Antônio Vieira, não seriam o suficiente para nos dizer quem foi (ou quem foram) esse(s) Vieira(s), portanto, neste artigo, não traremos a biografia do jesuíta. As possíveis leituras e interpretações de seus sermões geralmente convergem para a construção da identidade de um só homem, por outro lado, as práticas sociais do jesuíta, no exercício do seu sacerdócio, apresentam-nos um homem de múltiplas atividades profissionais.

A produção literária ${ }^{2}$ do Padre Antônio Vieira, principalmente os seus sermões, tem sido uma fonte inesgotável para estudos e construção de conhecimentos, todavia, na condição de um trabalho acadêmico, esse extenso acervo requer um (re)corte, o que significa fazer uma criteriosa seleção dos textos que o pesquisador pretende analisar, valendo-se da luz incolor do tempo histórico, da complexidade e da universalidade que a obra de Vieira adquire nos mais variados campos do conhecimento. Primeiramente, porque coexistem os aspectos uno e múltiplo na essência deste sujeito - Padre Antônio Vieira - os quais transcendem a sua própria existência no tempo e no espaço. Aqui ocorre um perigo teórico, como diz Neves:

0 perigo teórico mais relevante que se corre ao tratar de Vieira é, precisamente, o de se deixar tomar por esta permanência histórica rara e pela multiplicidade de formas de ação do jesuíta. 0 perigo está em se imaginar uma figura única, de se pensar em uma essência

20 adjetivo "literária", aqui, expressa todo o conjunto de produções escritas do jesuíta, incluindo as que nitidamente possuem aspectos da arte literária, como as metáforas em seus sermões. 
que atravessasse sua vida e obra fundido-as em uma unidade que tudo explicaria ou justificaria (NEVES, 2003, p. 44).

A observação de Neves constitui uma preocupação metodológica crucial para o nosso objeto de estudo ao pensarmos que é difícil imaginar como se deu a produção e escrita dos seus sermões: foram transcritos em que momento após sua explanação na homilia? Será que a transcrição reproduziu de fato o discurso proferido oralmente? Enfim, são inúmeras indagações as quais não teremos como responder, mas fica a reflexão que pensar em uma unidade de imagem do Padre Antônio Vieira, que tudo explicaria e resumiria sobre ele, seria impossível.

Quando nos referimos a análise dos discursos do jesuíta, com tantas habilidades e funções (missionário, político, orador, pregador, sermonista, etc.), que desempenhou na província, o uno e múltiplo, que coexistem em um indivíduo tão complexo, se articulam como obstáculos a uma compreensão teórica mais profunda e igualmente complexa.

As produções do jesuíta ora nos apresenta um Vieira multifacetado, múltiplo, fragmentado em outros Vieiras (orador sacro, diplomata, missionário, escritor, administrador eclesiástico, político), ora nos apresenta um Vieira denso, concentrado, uno e mítico (como se fosse um só, do qual emanariam cada uma das suas outras faces).

Além deste caráter duplo (uno e multi), ambíguo e, concomitantemente, antagônico do jesuíta, o uso acentuado de antíteses em sua retórica e o destaque para a temática do conflito existencial nos permitem caracterizar o seu discurso como um discurso oximorônico ${ }^{3}$, não só pelo uso dos oxímoros,

30 oxímoro é o mesmo que o paradoxo, uma figura de linguagem que aproxima termos ou expressões contrastantes e contraditórios num só pensamento. Ex: Rios de neve em fogo convertido (Gregório de Matos). mas também pelo uso retórico do silogismo e dos sofismas que muitas vezes se fundamentam na contradição ou oposição de ideias para atingir a persuasão.

Acreditamos que os "poderes" conferidos a Vieira pela Coroa para sua atuação nas terras maranhenses também possam ter corroborado para essa excentricidade complexa do jesuíta. Aliás, era surpreendente a liberdade com a qual, nestas terras, o missionário se dirigia aos ouvintes, a maneira como apontava as faltas, listava os defeitos e falava as verdades: "no Maranhão o padre sentia-se em casa, ficando mais à vontade para chamar a atenção - 'tenho dito tantas verdades, com tanta liberdade, a tão grandes ouvidos'[...]" (BRANDÃO, 1979, p. 32).

0 crítico literário Alfredo Bosi afirma que "existe um Vieira brasileiro, um Vieira português e um Vieira europeu [...]" (BOSI, 2001, p. 121). Outros pesquisadores, como Brandão (1979), acreditam que haja um Vieira maranhense. Pregou nas províncias de Pernambuco e da Bahia. Todavia, em nenhuma delas, encontraríamos um Vieira mais brasileiro do que no Maranhão, pois "[...] o Maranhão foi fonte de inspiração e mais ainda, de vida na obra de Vieira. Um Vieira muito mais atuante e vivo que aquele dos volteios barrocos, dos cultismos e conceptismos" (BRANDÃO, 1979, p. 32). Até que ponto podemos afirmar que essa construção ideológica é mais um mito ${ }^{4}$ ?

Acreditamos que o diálogo sobre essa questão é um "fio condutor" na percepção do imaginário social em Vieira e fica ainda

4 Conforme Cassirer (2006), em Mito e Linguagem., adotamos este conceito porque esse autor vem afirmar que "o homem moderno passou a adotar o conhecimento mítico em depreciação ao conhecimento científico deixando de lado uma história de racionalização. Utilizamos a palavra mito neste artigo a partir da compreensão de Cassirer. 
mais interessante se colocarmos alguns contrapontos: será que esta denominação de "Vieira brasileiro, Vieira português, Vieira europeu", cunhada por Bosi (2001), aponta apenas para posições espaciais (geográficas) que o jesuíta ocupara durante as suas produções, já que esteve no Brasil, em Portugal, em Roma, na Holanda, na França (PELOSO, 2007) ou há muito mais implicações (socioculturais, ideológicas, temporais, até mesmo religiosas) nessas nomenclaturas? Pensar um "Vieira maranhense", como afirmou Brandão (1979), não seria fragmentá -lo mais ainda dentro destas posições que mencionamos na questão anterior?

Como vemos, são entraves teóricos que exigem cuidado do pesquisador ao olhar o objeto de estudo. Por se tratar de uma pesquisa na qual o tema se erige a partir dos discursos do Padre Antônio Vieira, buscamos vincular o nosso olhar a um objeto de estudo bastante explorado na Análise do Discurso e também muito recorrente nos estudos em Psicologia Social: a noção de sujeito, na tentativa de nos aproximarmos de um Vieira que represente a ideologia (visão de mundo) que ele próprio sustenta, cujas imagens e símbolos estão condicionados a sua própria condição histórica.

O caráter uno e múltiplo de Vieira se redobra em seu pensamento simbólico, sua consciência indireta ${ }^{5}$ apresenta à consciên-

5 Para Durand (1988), em A Imaginação Simbólica, a consciência dispõe de duas maneiras de representar o mundo: a primeira, representação direta, dá-se através da percepção na presença do objeto; a segunda, representação indireta, ocorre na ausência do objeto e por meio de uma imagem. Tem-se, assim, um contínuo, onde a consciência dispõe de diferentes graus da imagem, cujos dois extremos seriam constituídos "pela adequação total, a presença perceptiva, ou a inadequação mais acentuada, ou seja, um signo eternamente privado do significado, e veremos que esse signo longínquo nada mais é do que o símbolo" (DURAND, 1988, p. 11-12). cia o objeto ausente em forma de imagem. São essas imagens que buscaremos analisar em seus sermões. No dizer de Eliade:

O pensamento simbólico não é uma área exclusiva da criança, do poeta ou do desequilibrado: ela é consubstancial ao ser humano; precede a linguagem e a razão discursiva. 0 símbolo revela certos aspectos da realidade - os mais profundos - que desfiam qualquer outro meio de conhecimento. As imagens, os símbolos e os mitos são criações irresponsáveis da psique; elas respondem a uma necessidade e preenchem uma função: revelar as mais secretas modalidades do ser. Por isso, seu estudo nos permite melhor conhecer o homem, "o homem simplesmente", aquele que ainda não se compôs com as condições da história. Cada ser histórico traz em si uma grande parte da humanidade anterior à História (ELIADE, 2002, p. 9).

Como vemos, Eliade (2002) enfatiza que as imagens, os símbolos e os mitos revelam as mais secretas modalidades do ser, justamente o que nos interessa nesta pesquisa, em relação ao ser Padre Antônio Vieira. 0 uso do termo ser que se refere ao humano é muito comum nas pesquisas em ciências humanas e sociais, todavia utilizaremos com maior frequência o termo sujeito, a fim de nos aproximarmos do ser histórico, ou seja, do sujeito histórico que reflete, consciente ou inconscientemente, as circunstâncias de seu tempo.

Na tentativa de compreender melhor este sujeito, utilizaremos, também, como referencial teórico os escritos de Mikhail Bakhtin reunidos na Estética da Criação Verbal, em cuja produção se encontra uma concepção dialógica de língua e, consequentemente, de sujeito:

Nossa fala, isto é, nossos enunciados (que incluem as obras literárias), estão repletos de palavras dos outros, caracterizadas, em graus variáveis, pela alteridade ou pela assimilação, caracterizadas, também em graus 
variáveis, por um emprego consciente e decalcado (BAKHTIN, 1997, p. 315).

Na citação acima, vale a pena reforçar que as palavras "dos outros", conforme menciona Bakhtin, são uma das categorias mais complexas para a compreensão da teoria do discurso do pensador russo. Quem seriam os outros nos discursos de Vieira? Pergunta muito difícil de se responder, quando seria impossível identificar todos os discursos dos outros que contribuíram para a construção do sujeito Antônio Vieira, padre ou não.

Na próxima seção, discutiremos um pouco mais sobre este sentido dos outros na teoria dialógica de Bakhtin, relacionando com os aspectos uno e múltiplo do Padre Antônio Vieira em seus sermões.

\section{O sujeito Padre Antônio Vieira e a concepção dialógica de Mikhail Bakhtin}

Mikhail Bakhtin (1997) traz em seu pensamento a ideia de língua como algo heterogêneo, suscetível a mudanças históricas, sociais e culturais. É justamente este ponto de observação da linguagem que nos interessa para tentar compreender a construção dos discursos do Padre Antônio Vieira no Maranhão do século XVII.

Para Ribeiro, "Bakhtin trabalha com um mundo em movimento e em perene transformação, seu objeto está sempre em processo, não se submete a uma forma fixa e imutável" (RIBEIRO, 2011, p. 5), ou seja, a linguagem em constante movimento deve ser observada em sua relação dialógica:

Para ele [Bakhtin] o único objeto real e material de que dispomos para entender o fenômeno da linguagem humana é o exercício da fala em sociedade. A língua falada, nas casas e nas feiras, na rua e na igreja, no quartel e na repartição, no baile e no bordel, é sempre o que existe de materialmente palpável para o estudo. Para ele, a língua - que Saussure considera o objeto da linguística - não passa de um modelo abstrato, construído pelo teórico a partir da linguagem viva e real. Coerentemente Saussure afirmava que "não é o objeto que precede o ponto de vista, mas é o ponto de vista que cria o objeto". No caso da linguística é exatamente o que ocorre: o seu objeto é criado a partir do ponto de vista de que a linguagem humana não pode ser objeto de conhecimento científico, assim como o exercício da fala (RIBEIRO, 2011, p. 4).

Ribeiro (2011) aponta a fala em sociedade como um objeto real e material essencial para a compreensão do fenômeno da linguagem humana. Essa concepção bakhtiniana elucida a importância da fala enquanto dinamismo organizador do social, pois é através da língua falada nas práticas sociais cotidianas (nas casas, feiras, ruas, igrejas, quartéis, repartições, bailes, bordéis, etc.), que a linguagem se constitui, com o mundo em movimento e constante transformação.

Assim, a linguagem não pode ser um objeto de estudo estático, fixo e imóvel. A palavra, como também a oração pura e simples, não requer ato comunicativo, pode ser retirada do ato comunicativo, porque não necessita de uma resposta por parte do outro na relação dialógica. Uma vez pronunciada, pode não ser precisa e possui uma efetivação abstrata; é o término do elemento e não do todo.

Para Bakhtin (1997), a palavra ou a oração sozinha não tem autoria, só a partir do momento em que se torna um enunciado, em uma situação discursiva, é que passa a representar a intenção do falante. Quando inserimos a palavra ou oração em um discurso, escolhemos as palavras de acordo com as especificidades do gênero discursi- 
vo utilizado no momento. Já que o gênero é uma forma típica do enunciado, no gênero a palavra incorpora esta tipicidade.

As palavras são incorporadas ao nosso discurso a partir de enunciados de outras pessoas, dessa maneira, carregam enunciações individuais que expressam as experiências individuais do falante, mas também carregam enunciações coletivas, de outros discursos apreendidos pelo falante em suas interações sociais com os outros sujeitos.

Bakhtin (1997) considera que a palavra não é dotada apenas de expressão típica, mas também de expressão individual, já que nos comunicamos por meio de enunciações individuais. E que as palavras: "Essas palavras dos outros trazem consigo a sua expressão, o seu tom valorativo que assimilamos, reelaboramos, e reacentuamos" (p. 295). À diferença do enunciado, palavra e oração, são desprovidas de "endereçamento"; não são ditas para alguém, não pertencem e nem se referem a ninguém, carecem de qualquer tipo de relação com o dizer do outro.

Para compreender melhor a relação dialógica, Ribeiro (2011) aponta em sua análise sobre a linguagem na concepção bakhtiniana que "já que se trata de linguagem e não de língua, a unidade básica não pode ser o signo, mas o enunciado" (RIBEIRO, 2011, p. 5).

Um enunciado não é um signo pela simples razão de que para existir ele exige a presença de um enunciador (quem fala, quem escreve) e de um receptor (quem ouve, quem lê). O signo faz parte de uma construção teórica que dispensa os sujeitos reais do discurso. Um signo, num dicionário, não é e não pode ser um enunciado. Este exige uma realização histórica. Um enunciado acontece em um determinado local e em um tempo determinado, é produzido por um sujeito histórico e recebido por outro. Cada enunciado é único e irrepetível. A mesma frase, exatamente a mesma, pronunciada em situações sociais diferentes, ainda que pelo mesmo enunciador, não constitui um mesmo enunciado e não pode constituir. Imaginem que, daqui a algumas horas, eu leia este mesmo texto, palavra a palavra, na Estação Rodoviária de Campos, para um público que não esperava ouvir-me. Será o mesmo texto, mas seguramente não o mesmo enunciado. Aqui, leio uma palestra para um público que, presumivelmente (eu espero!), deseja ouvir-me dissertar sobre as questões da linguagem num teórico de nome estrangeiro e complicado. Lá, as pessoas estarão possivelmente esperando as chamadas para as suas viagens $\mathrm{e}$ sem nenhum interesse pelas coisas que eu venha a dizer. Tudo o que conseguirei é uma fama de maluco, maior do que a já carrego, por ser professor universitário nesse nosso triste país.

Para Bakhtin (1997), língua e sujeito são permeados de discursos alheios e de relações dialógicas (de confronto, acusação, negação, recusa...); daí, pode-se depreender que o sujeito se constitui na sua relação com os outros, "as palavras dos outros introduzem sua própria expressividade, seu tom valorativo, que assimilamos, reestruturamos, modificamos" (BAKHTIN, 1997, p. 315).

Um outro traço constitutivo do enunciado é o fato dele ser produzido para alguém. E que as palavras são incorporadas ao nosso discurso a partir de enunciados de outras pessoas. As enunciações em suas relações dialógicas, somadas a outros aspectos, tais quais os que pertencem ao campo linguístico -, marcam percursos traçados pelo sujeito $\mathrm{e}(\mathrm{m})$ construção da linguagem.

Para Bakhtin (1997), cada ato de enunciação é composto por diversas "vozes". Assim, cada palavra, oração ou ato de fala vem dotado de assimilações, percepções, sentidos, valores construídos pelos outros, os quais vamos absorvendo em nossas interações, relações e práticas sociais. Isto é o que o autor denomina de polifonia. Estas vozes 
"dialogam" dentro do discurso, não se trata apenas de uma retomada. Este diálogo polifônico é construído histórica e socialmente.

Por isso, reforçamos a imagem do uno e do múltiplo nos discursos de Vieira, por entendermos que em seus sermões a voz do sujeito Padre Antônio Vieira está eivada de múltiplos discursos que contribuíram para a construção da consciência individual do falante. Só pensamos graças a um contato permanente com os pensamentos alheios, pensamento este expresso no enunciado. Dessa forma, a consciência individual é resultante de um diálogo entre interconsciências.

O Maranhão que aparece nos discursos de Vieira é uma província da Colônia que, antes de sua presença física na terra dos maranaguaras $^{6}$, chegou à consciência do jesuíta por diferentes fontes discursivas, como os discursos de seus superiores que o enviaram àquela missão e os demais interlocutores com os quais dialogara até a sua chegada.

0 enunciado não é um conceito meramente formal; um enunciado é sempre um acontecimento. Ele demanda uma situação histórica definida, atores sociais plenamente identificados, o compartilhamento de uma mesma cultura e o estabelecimento necessário de um diálogo. Todo enunciado demanda outro a que responde ou outro que o responderá. Ninguém cria um enunciado sem que seja para ser respondido. Mesmo isto que eu agora leio, ainda que não venha a receber respostas exteriorizadas, por certo as pro-

6 Termo utilizado por Eloy Coelho Netto (1985) para denominar os índios que habitavam o Maranhão à época da colonização: "Estes índios tupinambás na ilha de Upaon-Açu tomam o nome de maranaguaras - Maranã - semelhante ao mar, e guará - habitante. Nesta Província havia nações Tupinambás, Tapuias, Tamarambeses, sempre em desabrida e cruel luta entre si, sem trégua e descanso, sem piedade e remorsos" (COELHO NETTO, 1985, p. 32-33). vocará interiormente e, desde já, esboço as minhas réplicas neste diálogo sem fim. (RIBEIRO, 2011, p. 5).

A relação dialógica não acontece somente entre discursos interpessoais (seja escrito ou verbal), embora tenha se originado dentro dessa concepção; ela engloba a diversidade das práticas discursivas de maneira mais ampla e aberta. Assim, todo discurso não é uma obra fechada e acabada de apenas um indivíduo, mas é um processo heterogêneo, conjunção de discursos entre o eu e o outro. 0 dialogismo pode ser aplicado à relação entre as línguas, as literaturas, os gêneros, os estilos e até mesmo entre as culturas, pois todos esses itens trazem em comum a linguagem, corroborando a busca da totalidade que norteia o pensamento bakhtiniano.

Esta concepção bakhtiniana de sujeito pode nos ajudar a visualizar com outros olhos o(s) sujeito(s) Antônio Vieira em suas diferentes relações com outros de sua época, analisando os enunciados construídos em suas cartas e, principalmente, em seus sermões, pois, como afirma Bakhtin (1997),

0 enunciado está repleto dos ecos e lembranças de outros enunciados, aos quais está vinculado no interior de uma esfera comum da comunicação verbal. 0 enunciado deve ser considerado acima de tudo como uma resposta a enunciados anteriores dentro de uma dada esfera (a palavra "resposta" é empregada aqui no sentido lato): refuta-os, confirma-os, completa-os, baseia-se neles, supõe-nos conhecidos e, de um modo ou de outro, conta com eles. Não se pode esquecer que o enunciado ocupa uma posição definida numa dada esfera da comunicação verbal relativa a um dado problema, a uma dada questão, etc. Não podemos determinar nossa posição sem correlacioná-la com outras posições. É por esta razão que o enunciado é repleto de reações-respostas a outros enunciados numa dada esfera da 
comunicação verbal (BAKHTIN, 1997, p. 317 , grifos nossos).

Destacamos a última oração porque focaliza bem um dos procedimentos metodológicos com o qual nos preocupamos nesta pesquisa: o enunciado como reação-resposta a outros enunciados numa dada esfera da comunicação. Este é, sem dúvida, um dos exercícios que melhor desenvolveu em seu sermonário, o Padre Antônio Vieira. Pretendemos analisar estes enunciados (contidos nos sermões e cartas) a partir de suas continuidades, ratificações, confirmações e, por outro lado, a partir de suas rupturas, contradições, negações, objetivando diminuir o quanto possível os riscos de reducionismos dos ecos e lembranças que possam expressar os enunciados do missionário.

Como lembra Bakhtin (1997),

a expressividade da palavra isolada não é, pois, propriedade da própria palavra, enquanto unidade da língua, e não decorre diretamente de sua significação. Ela se prende quer à expressividade padrão de um gênero, quer à expressividade individual do outro que converte a palavra numa espécie de representante do enunciado em seu todo - um todo por ser instância determinada de um juízo de valor (BAKHTIN, 1997, p. 315).

Os enunciados (discursos retóricos) de Vieira, o uso da linguagem barroca, a sua oratória, ora sarcástica/lúdica, ora explosiva, conferem-lhe uma dimensão complexa; mais do que isso, demonstram a própria complexidade do sujeito que os constrói e refletem práticas sociais de um contexto deveras conturbado.

Só para ilustrar, o século XVII tanto para Portugal quanto para o Brasil foi marcado por grande turbulência. Lá, além dos impactos causados pela União Ibérica ${ }^{7}$, ainda

7 Em 1578, D. Sebastião, Rei de Portugal, procurava restaurar o espírito das cruzadas. Ao tentar conquistar o norte da África, foi derrotado na tiveram que lidar com crises político-econômicas que duraram décadas; aqui, as disputas entre jesuítas e colonos mediante a escravização dos índios requeriam medidas diplomáticas estratégicas da Companhia de Jesus sem atingir diretamente os interesses econômicos da Coroa, visto que ambas partilhavam fins em comum.

O sujeito Padre Antônio Vieira aparecenos no século XVII de maneira excepcional, "com uma inteligência inquieta, sensibilidade aguçada, capaz de revelar traços da arte do seu tempo, ao lado de uma atitude crítica com relação a esta mesma arte" (CARVALHO, 2000, p. 36).

É inegável a capacidade de se adaptar aos contextos missionários aos quais era enviado para coordenar. Mais do que isso, o jesuíta conseguia transitar, nos seus discursos, da função de orador sacro à função de jurista defensor dos cativos (índios) que sofriam maltratos pelos fazendeiros do Maranhão.

Apesar da função política de defender os interesses da Coroa e da Companhia de Jesus, Vieira se apresentava sensível ao cenário em que se encontrava o Maranhão, assim, torna-se possível, através dos discursos do jesuíta, perceber a constituição simbólica de um imaginário social do Padre Antônio Vieira no Maranhão seiscentista.

batalha de Alcácer Quibir e desapareceu. Portugal viu-se mergulhado numa profunda crise político-sucessória, pois o jovem rei desaparecido não deixou herdeiros. Felipe II, Rei da Espanha, era neto do rei português à época da descoberta do Brasil, D. Manuel, e se considerava o legítimo herdeiro do trono português. Parte da nobreza de Portugal resistia à pretensão do monarca espanhol. 0 impasse político foi resolvido com o uso da força: Filipe II invadiu Portugal, em agosto de 1580 , e derrotou os exércitos lusitanos na batalha de Alcântara. Iniciava-se, nessa data, o período denominado União das Coroas Ibéricas (ou União Ibérica), no qual Portugal ficou sob o domínio da Espanha e que se estendeu até 1640 (CHACON, 2005). 
Os textos do Padre Antônio Vieira contêm uma produção laboriosa empenhada em um forte exercício retórico e oratório, tais quais lhe conferiram, entre os críticos literários, o lugar de expoente no uso do conceptismo em textos de língua portuguesa.

O conceptismo, mais do que um recurso literário, representa nos textos do jesuíta, uma ação sobre o mundo à sua volta. A força do seu discurso reflete uma série de contradições e divergências que apresentam elementos paradoxais e, por conseguinte, objetos discursivos paradoxais, marcantes nos textos produzidos - daí que sublinhamos este momento histórico-literário de Barroco.

Os argumentos discursivos do jesuíta são estruturados em ensinamentos que sublinhamos da Escolástica Medieval; dessa maneira, é comum que o jesuíta sempre busque um argumento lógico para fundamentar sua fé católica. Por isso, o uso da retórica como disciplina é um recurso indispensável na prática missionária do padre para fins de persuasão do público. Por conseguinte, estes recursos discursivos refletem a composição de um imaginário social fundamentado no poder da palavra, no labor de usá-la. Daí a frequência dos silogismos e sofismas. Sobre esse argumento, reforça Neves:

É preciso, na análise da retórica vieiriana, tomar em consideração que ela parece muito mais voltada para temas e formas tradicionais. Tem elementos claramente advindos da escolástica, da oratória medieval e da herança patrística do comentário interpretativo da Bíblia. Estas fontes, que Vieira elabora a seu modo particularíssimo, não estão, contudo a serviço do passado, apenas marcado por ele. 0 que soa, para este seu leitor, como estimulante paradoxal, é que o peso desse passado é voltado para a intervenção no presente e para a construção do futuro, de que falam especialmente seus livros pro- féticos, como a História do Futuro. (NEVES, 2003, p. 23)

Notamos que Vieira conseguia associar textos bíblicos - nem que para isso modificasse o enredo, ou qualquer outro elemento da narrativa - aos fatos sociais polêmicos no seu dia a dia. Todo o esforço dialético do padre orienta-se em construir uma argumentação que defenda os seus posicionamentos ideológicos, políticos, religiosos; cabe-nos, então, perceber esses discursos, suas contradições, rupturas, aproximações e continuidades com um projeto de estabelecimento da fé católica pelos soldados de Cristo, na terra dos papagaios.

Bakhtin (1997) propõe que o indivíduo se afaste o quanto possível dos objetos com os quais se relaciona a fim de que lhes perceba a real forma - a ordem do aleatório:

O que na vida, na cognição e no ato, designamos como objeto determinado, não recebe sua designação, seu rosto, senão através da nossa relação com ele: é nossa relação que determina o objeto e sua estrutura e não o contrário; é somente quando nossa relação se torna aleatória, como que caprichosa, quando nos afastamos da relação de princípio que estabelecemos com as coisas e com o mundo, que o objeto se nos torna alheio e fica autônomo, começa a se desagregar, abandonando-nos ao reino do aleatório no qual perdemos a nós mesmos e perdemos também a determinação estável do mundo. (BAKHTIN, 1997, p. 15).

Na perspectiva bakhtiniana, a busca de sentido do discurso se dá na constante continuidade, na análise de elos múltiplos entre a atividade de linguagem, suas motivações e determinações, visto que há um processo histórico de constituição das significações e, nesse percurso, podemos buscar pontos (sinais) para a constituição do imaginário social de uma determinada sociedade em uma determinada época. 
Quando trazemos esta discussão para a análise dos sermões de Vieira, encontramos um complexo de possibilidades que determinam o objeto de estudo deste trabalho, ao passo que, quanto mais tentamos nos aproximar do mesmo, mais nos sentimos distantes de sua apreensão, visto que se torna essencial o distanciamento para olharmos, por diferentes ângulos, a problemática em foco.

Na Análise do Discurso,

[...] o enunciado é um fenômeno complexo, polimorfo, desde que o analisemos não mais isoladamente, mas em sua relação com o autor (o locutor) e enquanto elo na cadeia da comunicação verbal, em sua relação com os outros enunciados (uma relação que não se costuma procurar no plano verbal, estilístico-composicional, mas no plano do objeto do sentido) (BAKHTIN, 1997, p. 319).

Esta citação de Bakhtin traz a preocupação do filósofo da linguagem com a importância da relação dialógica na construção da enunciação. É na relação do enunciado falante (autor) com os outros enunciados, que construímos o sentido da linguagem do autor. "A língua penetra na vida através dos enunciados concretos que a realizam, e é também através dos enunciados concretos que a vida penetra na língua" (BAKHTIN, 1997, p. 230).

De fato, é uma relação complexa, polimorfa, que vai para além do plano verbal, estilístico-composicional, material e formal da palavra ou oração, pois, reflete uma experiência social, histórica, interacional entre sujeitos nas suas práticas sociais. "Os enunciados e o tipo a que pertencem, ou seja, os gêneros do discurso, são as correias de transmissão que levam da história da sociedade à história da língua" (BAKHTIN, 1997, p. 285).

A presença do Padre Antônio Vieira, no Maranhão, portanto, leva-nos a refletir não só sobre a construção ideológica, retórica, teórica de seus textos, mas também sobre as condições de composição desses textos, seu ponto de vista histórico, político, geográfico, a situação em que ele se encontrava, sendo que isso reflete as suas práticas sociais, sua maneira de ver e pensar o mundo, seu imaginário social. Porém, como compreender a complexidade de seu pensamento e o imaginário social constituído por ele? Vamos dialogar sobre esta questão no próximo item durante as análises do Sermão da Primeira Dominga da Quaresma (1653).

\section{O Vieira do Maranhão: análise do Sermão da Primeira Dominga da \\ Quaresma}

Antônio Vieira foi, é, e provavelmente será objeto de estudo em diversos trabalhos acadêmicos nas mais variadas áreas do conhecimento - história, historiografia, literatura, sociologia, filosofia - visto que Vieira ainda é um ícone, ou símbolo iconográfico ${ }^{8}$ que, como tal, possibilita múltiplas interpretações e análises de seu imaginário, deixandonos, sem dúvida, um legado de conhecimentos a serem desvendados ainda por muitos outros pesquisadores.

A análise do Sermão da Primeira Dominga da Quaresma, que pretendemos desenvolver nesta seção, busca apontar e destacar os diferentes papéis simbólicos que o jesuíta desempenha enquanto missionário no Maranhão, no século XVII.

8 Para Durand, o símbolo iconográfico é a imagem pintada, esculpida etc., constituído de múltiplas redundâncias: "cópia" redundante de um lugar, de um rosto, de um modelo, com certeza, mas também da representação pelo espectador daquilo que o pintor já representou tecnicamente. O símbolo ... jamais é explicado de uma vez por todas, mas deve ser sempre decifrado de novo, assim como uma partitura musical nunca é decifrada de uma vez por todas, mas exige uma execução sempre nova (DURAND, 1988, p. 18). 
O Sermão da Primeira Dominga da Quaresma ou das Tentações (1653) é o primeiro, seguindo a cronologia, dos três grandes sermões proferidos por Pe. Antônio Vieira no Maranhão. A temática escolhida pelo jesuíta para este sermão retrata claramente a angústia do padre diante de problemas que, a priori, somente ele, a mando da Igreja e do Rei, poderia resolver.

Neste Sermão, Vieira se mostra indignado com a situação dos índios que eram catequizados (civilizados) pelas missões jesuíticas e, posteriormente, vendidos e comprados como objetos, como se suas almas não tivessem nenhum valor. Para os fazendeiros, comprar um índio "domesticado, civilizado" deixava de ser um transtorno ou futuro aborrecimento e se tornava um negócio lucrativo.

A autoridade civil, sustentando os padres, fixou na terra o elemento da reação à desagregação moral e de resistência à cobiça desenfreada dos colonos. Esta não se aquietou com facilidade. Houve várias manifestações para reenviar os padres. Mas a autoridade régia não cedeu. E os padres ficaram numa perpétua luta, em que umas vezes eram quase adorados, outras perseguidos e exilados (SOUZA, 1977, p. 6).

O cenário e o contexto, com o qual se deparava o missionário jesuíta, trazem em si uma contradição com o processo de evangelização do aborígine, visto que catequiza-se para libertar-lhes a alma e o corpo, todavia não havia esse entendimento entre colonos e jesuítas, pois estes tinham o interesse em ainda mantê-los cativos.

O Sermão da Primeira Dominga da Quaresma é dividido em seis partes, as quais podem ser ordenadas da seguinte maneira: I - introito, introdução ou exórdio; II e III exposição; IV e V - confirmação e VI - peroração.
No exórdio, são mencionadas as três tentações que Jesus teria sofrido pelo demônio: na primeira, o demônio ofereceu que fizesse das pedras pão; na segunda, aconselhou que se deitasse daquela torre abaixo; na terceira, pediu que caído o adorasse; e dentre elas é escolhida uma que seria, como diz o próprio Vieira, "a lança de que mais se fiava":

A que escolhi das três, não foi a primeira nem a segunda, senão a terceira e última, porque ela é a maior, porque ela é mais universal, ela é a mais poderosa, e ela é a mais própria desta terra em que estamos. Não debalde a reservou o demônio para o último encontro, como a lança de que mais se fiava; mas hoje lha havemos de quebrar nos olhos [...]" (VIEIRA (1653), 2008a, p. 101).

Os recursos anafóricos ${ }^{9}$ utilizados pelo missionário fortalecem a sua argumentação, e a sequência de superlativos absolutos conferem grandeza e gradação ao mote ${ }^{10}$ desta introdução: "mas hoje lha havemos de quebrar nos olhos". Vieira, com astúcia, aponta que no Maranhão a terceira tentação do demônio (também negada por Cristo, mas não pelos maranhenses) deitava e rolava (tirava proveito da situação): "A que diferente preço compra hoje o demônio as almas no Maranhão!" (VIEIRA (1653), 2008a, p. 106).

Na segunda parte, primeira da exposição, Vieira apresenta a frase na qual se baseará todo o sermão: "Haec omnia tibi dabo, si cadens adoraveris me (Tudo isto te darei se, prostrado, me adorares)" (VIEIRA(1653), 2008a, p. 101). Assim, correlaciona o valor das almas para o homem e para o demônio:

9 A anáfora é uma figura de linguagem que consiste na repetição de palavras, geralmente no início de versos ou orações (CEREJA, 1994, p. 186). Ex: Ela é ..., ela é..., ela é... (VIEIRA (1653), 2008a, p. 101).

10 Segundo o dicionário Larousse (2011), mote é "verso ou pequeno conjunto de versos usados como tema ou ponto de partida para o desenvolvimento do poema" (p. 433). 
"nós, os homens, como nos governamos pelos sentidos corporais, e a nossa alma é espiritual, não a conhecemos; e como não a conhecemos, não a estimamos, e por isso a damos tão barata" (VIEIRA (1653), 2008a, p. 102). 0 uso desta máxima ${ }^{11}$ demonstra o posicionamento político do jesuíta em relação aos mercadores de índios, esclarece-nos que o objetivo principal era criticar, nas homilias, a mercancia desenfreada e ilegal do aborígene.

A imagem simbólica ${ }^{12}$ do valor da mer-

11 Máximas são frases tidas como verdades absolutas e muito utilizadas nos discursos retóricos.

12 A imagem simbólica, ou seja, aquela que não depende diretamente do senso da percepção, parece ser refratária a qualquer objetividade explicativa categórica ou universal e, simultaneamente, permeável aos mais distintos métodos de interpretação. As diversas escolas psicanalíticas, por exemplo, podem ser classificadas através do tipo de pulsão que priorizam no momento da interpretação. Tornou-se necessária, atualmente, uma nova compreensão dessas hermenêuticas e uma revisão da concepção pulsional do símbolo. A Filosofia, a Antropologia e os avanços da pesquisa clínica sobre a imagem vêm fornecendo elementos para essa nova compreensão. Durand (1997) desenvolve em As estruturas antropológicas do imaginário uma topografia do imaginário avessa às reduções sociológicas e psicológicas da imagem ou, em uma expressão do autor, um jardim das imagens primordiais da espécie humana. Seu trabalho representa também um desenvolvimento da noção junguiana de arquétipo e um projeto de sistematizar aquilo que a teoria junguiana deixou em aberto, ou seja, uma terminologia precisa acerca da imagem e do imaginário e uma arquetipologia geral. Dessa forma, as imagens simbólicas são interpretadas a partir das relações que estabelecem entre si, de seu arranjo e convergência em torno de uma determinada estrutura. Assim, a imagem do fogo pode ser tanto um símbolo de intimidade e de aconchego quando é o calor que aquece uma cabana ao cair da tarde (estruturação mística), quanto um símbolo diurno quando é a arma de ataque do herói contra um monstro devorador (estruturação heroica). Ou ainda um símbolo de iniciação, quando é a brasa que queima o corpo do neófito durante o ritual de passagem (estruturação sintética). cadoria serve de ponto de partida para os schemes $^{13}$ que afloram na imaginação jesuítica de Vieira. Todavia, o universo discursivo do jesuíta, do sujeito Vieira, no sentido bakhthiniano, reconstrói essa imagem da mercadoria substituindo o objeto da relação mercadológica: retira a matéria (o índio) do papel de mercadoria e coloca a alma (dos próprios fazendeiros e dos índios) como mercadoria. É importante ressaltar que ele encontrou esse scheme no contexto das práticas sociais dos fazendeiros do Maranhão àquela época e demonstra quão grande mercador o demônio se torna em relação a estes fazendeiros: "A que diferente preço compra hoje o demônio as almas no Maranhão!" (VIEIRA (1653), 2008a, p. 106).

Vieira pretende enfatizar que não é só a alma do índio que serve de mercadoria, mas a alma do fazendeiro que descumpre a lei (do Rei e, simultaneamente, de Deus) e, desta maneira, vende sua alma ao diabo. Assim, o jesuíta destaca a importância da salvação da alma para adentrar no Reino dos Céus, servir ao Rei e a Deus em vez de tornar sua alma uma grande mercadoria para o demônio.

Ao destacar a importância da salvação da alma, o jesuíta traz ao cenário um combate entre dois componentes humanos distintos e simultaneamente complementares - a rivalidade entre corpo e alma - e destaca o que este combate representa para a Compa-

13 Para Durand (1997), schèmes ou schémas são formas de percepção de certos esquemas reflexológicos realizados pelo corpo humano que vêm se enquadrar e assimilar aos esquemas motores primitivos. Dessa maneira, "o corpo inteiro colabora na constituição da imagem". Desde pequenos, aprendemos a nos apossar de nossos brinquedos, se alguém os toma gritamos, brigamos, batemos, mordemos, reagimos geralmente de maneira agressiva, quando adulto nos apossamos de mercadorias que quando tomadas, tendemos a reagir da mesma maneira de quando éramos crianças. 
nhia de Jesus, no processo de evangelização dos índios: ambos representam o exercício da dialética, a luta constante entre os opostos, o concreto (corpo) e o abstrato (a alma), respectivamente, entre o profano e o sagrado, o impuro e puro, o pecado e perdão.

0 índio possui uma relação com a natureza bem diferente da que tem o colonizador europeu. "O jesuíta vê a natureza como algo luxuriante, soberbo, avassalador, misterioso, grávido de perigos e surpresas" (NEVES, 1978, p. 53). O índio em contato com a natureza interage em igualdade com esta, mais animal, menos homem (sob a ótica das civilizações modernas). "O corpo é o lugar de inscrição dos aspectos da animalidade, da escassa humanidade" (idem).

Ana Lúcia Oliveira faz alusão a estes contrastes ao ressaltar que

No contato que estabelecem com o gentio, os jesuítas e cronistas do descobrimento denominam a pluralidade desses povos como 'índios' e, simultaneamente, produzem uma essência, o "índio", que pode ser definida como alma selvagem ou como animal sem alma" (OLIVEIRA, 2011a, p. 30).

Por esta razão, o trabalho da Companhia de Jesus exerce um papel importantíssimo, tanto para o Clero quanto para a Coroa, que se definia na conversão do gentio ao Catolicismo. Os jesuítas viam como obstáculos primários, no trabalho de catequese, além da linguagem, a educação do "corpo" do nativo. Era preciso mostrar-lhes que o corpo é impuro, ensinando-lhes comportamentos (andar vestidos, flagelações, jejuns, abstinências) que, a princípio, não faziam sentido para o aborígene.

Os padrões de comportamento e uso do corpo, conforme o modelo cultural europeu eram completamente desconhecidos pelos índios, e esse desconhecimento "é sinônimo de animalidade na medida em que não consegue estabelecer fronteiras internas às tribos, e fronteiras entre as tribos e a natureza" (NEVES, 1978, p. 56).

A dialética do exterior e do interior ${ }^{14}$ (BACHELARD, 1998, p. 215) se dinamiza na relação entre o corpo e as regras de funcionamento deste corpo que, a priori, encontra seus fundamentos na natureza, esta que os jesuítas veem como espaço profano e deve ser aos poucos afastada do selvagem para apresentá-lo à civilização - um espaço sagrado, daí a importância das aldeias no processo de catequização do aborígene. No entanto, frise-se que para o índio não há desconhecimento, uma vez que ele possuía uma relação de harmonia e equilíbrio com a natureza, e suas formas de comportamento, uso do corpo, relações com outras tribos, canibalismo, não representavam de nenhuma forma o desconhecimento de seu próprio corpo e suas relações com a natureza.

Sendo a alma o foco do sermão de Vieira, ele questiona ao público:

Pesai primeiro o que é uma alma, pesai primeiro o que vale, e o que custou, e depois eu vos dou licença que a vendais embora. Mas em que balanças se há de pesar uma alma? Nas balanças do juízo humano não, porque são mui falsas. Tomai as balanças do demônio na mão, ponde de uma parte o mundo todo, e da outra uma alma, e achareis que

14 Gaston Bachelard (1998) aborda a questão da "dialética entre o exterior e o interior" na sua obra A Poética do Espaço, destacando que "na superfície do ser, nessa região em que o ser quer se manifestar e quer se ocultar, os movimentos de fechamento e abertura são tão numerosos, são frequentemente invertidos, tão carregados de hesitação, que poderíamos concluir com esta fórmula: o homem é o ser entreaberto" (BACHELARD, 1998, p. 225). Dessa forma, podemos compreender o corpo como uma porta ou janela para o exterior e o interior do ser humano, visto que por ele transitam as forças que se digladiam entre o exterior e o interior do ser, por conseguinte, era esta "via de trânsito" que os jesuítas queriam controlar com as missões. 
pesa mais a vossa alma que todo o mundo (VIEIRA (1653), 2008a, p. 103-104).

0 jesuíta critica severamente os fazendeiros do Maranhão e depois de ter citado um versículo de Isaías (Isaías 58, 1) - que traduz assim: "Brada, pregador, e não cesses; levanta a tua voz como trombeta, desengana o meu povo, anuncia-lhe os seus pecados e dize-lhe o estado em que estão" (VIEIRA [1653], 2008a, p. 108) - anuncia aos colonos fazendeiros do Maranhão o papel de sacerdote, político e jurista que viera desempenhar na Colônia, e continua:

"Cristãos, Deus me manda desenganar-vos, e eu vos desengano da parte de Deus. Todos estais em pecado mortal; todos viveis e morreis em estado de condenação, e todos vós ides direito ao inferno. Já lá estão muitos, e vós também estareis cedo com eles, se não mudardes de vida" (VIEIRA [1653], 1998a, p. 108).

A segunda parte da exposição do sermão, Vieira finaliza com uma ofensiva direta aos fazendeiros:

A que diferente preço compra hoje o demônio as almas, do que oferecia por elas antigamente! Já nesta nossa terra vos digo eu! Nenhuma feira tem o demônio no mundo onde lhe saiam mais baratas: no nosso Evangelho ofereceu todos os reinos do mundo por uma alma, no Maranhão não é necessário ao demônio tanta bolsa pra comprar todas: não é necessário oferecer reinos, não é necessário oferecer cidades, nem vilas, nem aldeias. Basta acenar o diabo com um tujupar de pindoba, e dois tapuias, e logo está adorado com os ambos os joelhos [...] - Oh! Que feira tão barata! Negro por alma, e mais negra ela que ele! Esse negro será teu escravo esses poucos dias que viver, e tua alma será minha escrava por toda a eternidade, enquanto Deus for Deus. Este é o contrato que o demônio faz convosco, e não só lho aceitais, senão que lhe dais o vosso dinheiro em cima. (VIEIRA (1653), 2008a, p. 106).
Nessa prédica, o missionário utiliza o valor das almas para demonstrar que no Maranhão elas são vendidas a um preço irrisório, isto é, os fazendeiros estão mais preocupados em escravizar os índios (corpo e alma) do que em salvar as suas próprias almas perante a Igreja.

Na terceira parte do sermão, segunda da exposição, Vieira demonstra sua habilidade de bom pregador, bom amigo, pois avisa aos fazendeiros do Maranhão do perigo que corriam e tenta convencê-los de que, naquela Quaresma, o que Deus queria é que eles parassem de transgredir e libertassem os índios para que houvesse perdão de seus pecados.

- Sabeis, cristãos, sabeis, nobreza e povo do Maranhão, o qual é o jejum que que Deus de vós esta Quaresma? Que solteis as ataduras da injustiça, e que deixeis ir livres os que tendes cativos e oprimidos. Estes são os pecados do Maranhão, estes são os que Deus me manda que vos anuncie. - Cristãos, Deus me manda desenganar-vos, e eu vos desengano da parte de Deus. Todos estais em pecado mortal, todos viveis e morreis em estado de condenação, e todos vós ides direitos ao inferno. Já lá estão muitos, e vós também estareis cedo com eles, se não mudardes de vida (VIEIRA (1653), 2008a, p. 108).

Logo em seguida, o jesuíta critica os cativeiros injustos, essa escravização ilegal do indígena, visto que tal atitude dos fazendeiros contrariava os planos da Companhia de Jesus: "Sabeis quem traz pragas às terras? Cativeiros injustos. Quem trouxe ao Maranhão a praga dos holandeses? Quem trouxe a pragas das bexigas? Quem trouxe a esterilidade? Estes cativeiros" (VIEIRA (1653), 2008a, p. 109).

Existe no texto dentre outras figuras uma que se destaca, a alegoria, recurso que o orador utiliza para fazer a plateia se lembrar da Nação de Israel que vivia no Egito, 
cativa do faraó. Esse cativeiro motivou a ira de Deus que convocou Moisés e seu famoso cajado a lançar as pragas ao Egito.

Vieira lembra que, ao permitir que Moisés levasse os escravos do Egito, o Faraó, com todo o seu poder, tentou recuperá-los, mas o que aconteceu? "Abre-se o Mar Vermelho, para que passassem os cativos a pé enxuto - que sabes Deus fazer milagres para libertar cativos" (VIEIRA (1653), 2008a, p. 110). 0 jesuíta destaca ainda a descrição de Moisés da passagem bíblica no Êxodos (15, 10.12): "que caiu sobre eles e os afogou o mar, e os comeu e engoliu a terra" (VIEIRA (1653), 2008a, p. 110), questionando: "se os afogou o mar, como os tragou a terra", ele próprio responde: "Aqueles homens, como nós, tinham corpo e alma: os corpos afogou -os a água, porque ficaram no fundo do mar; as almas tragou-as a terra, porque desceram ao profundo do inferno" (VIEIRA (1653), 2008a, p. 110).

É interessante como algumas imagens são recorrentes na imaginação humana e se exteriorizam através dos arquétipos ${ }^{15}$ (JUNG, 1996) e símbolos isomorfos (DURAND, 1997) em diferentes tempo e espaço. A passagem do Mar Vermelho, em que o mar traga os corpos, e a terra traga as almas, apresenta um esquema de ritmização da queda (DURAND, 1997, p. 215) muito diferente do esquema do peixe engolidor, ritmização do engolimento, de que iremos tratar mais à frente, no quarto capítulo, no Sermão de Santo Antônio aos peixes, e que, ao longo da análise destes sermões, leva-nos para os arquétipos cíclicos ${ }^{16}$ propriamente ditos.

15 Para Jung (1996), os arquétipos são entendidos como resíduos arcaicos, isto é, formas mentais cuja presença não encontra explicação alguma na vida do indivíduo e que parecem, antes, formas primitivas e inatas, representando uma herança do espírito humano (JUNG, 1996, p. 63).

16 Arquétipos cíclicos são aqueles esquemas da imaginação humana que se repetem represen-
Ao citar a passagem bíblica do Mar Vermelho como exemplo da punição para aqueles que pecam, porque cativam, Vieira utilizou duas imagens catamórficas muito interessantes: o abismo e o esmagamento. 0 fundo do mar é o lugar do abismo e a queda das águas sobre os soldados e o Faraó representam o esquema do esmagamento.

Há uma passagem do sermão em que Vieira, além de grande pregador, demonstra sua habilidade discursiva forense, utilizando os textos da escritura sagrada, como os relativos à fuga de Moisés do Egito, através do Mar Vermelho, para justificar que todo o povo, que aprisiona e escraviza outro, será punido com o inferno: "Abre-se o Mar Vermelho, para que passassem os cativos a pé enxuto - que sabe Deus fazer milagres para libertar cativos" (VIEIRA [1653], 2008a, p. 110). Quanto ao faraó e seus soldados, foram castigados, esmagados pela força das águas que caíram sobre eles quando o mar se fechou.

Na quarta parte do sermão, primeira da confirmação, deparamo-nos com um Vieira preocupado com as questões sociais do Maranhão: "o projeto da Companhia de Jesus de catequizar os nativos, convertê-los em leais vassalos da Coroa portuguesa reunindo-os nos chamados aldeamentos d'el-rei, administrados exclusivamente pelos jesuítas" (NEVES, 2004, p. 45), tal projeto de concorrer com o duro pragmatismo dos colonos que, no Maranhão e no Pará, alegavam não ter mão de obra disponível que não fosse o trabalho forçado dos índios.

tados pelos símbolos cíclicos, do eterno retorno, da repetição, como: o ano novo, as estações do ano, as fases da lua, que estão relacionadas na imaginação humana às plantações e o seu ciclo, aos ciclos menstruais, aos cortes de cabelo, à piracema, à circuncisão, às cerimônias iniciáticas (batismo, formaturas, promoções), práticas orgiásticas (carnaval, bailes), etc. 
Mediante tais complicações, Vieira exprime a sua indignação à desumana exploração de que os índios eram vítimas, nesta exclamação: "Ah fazendas do Maranhão, que se esses mantos e essas capas se torceram, haviam de lançar sangue!” (VIEIRA (1653), 2008a, p. 112).

Ao lembrar que os cativeiros injustos resultam em punições divinas para aqueles que cativam, o jesuíta desenvolve também a noção de cativeiros justos. Fala inclusive das pragas jogadas sobre o povo egípcio e dos perigos das tentações com as quais o demônio se mascara para nos enganar. Mas o próprio Vieira desenvolve, no sermão, teorias ou argumentos que justifiquem a necessidade dos cativeiros justos ou cativeiros lícitos.

Como bom "jurista"17, o jesuíta traz à questão o que é lícito e ilícito e estabelece um jogo dialético e lúdico com as escrituras sagradas, no qual insere o poder e a soberania do Rei como artifício de persuasão de sua argumentação:

El-Rei poderá mandar que os cativos sejam livres; mas que os livres sejam cativos, não chega lá sua jurisdição. Se tal proposta fosse ao reino, as pedras da rua se haviam de levantar contra os homens do Maranhão. Mas se a proposta for lícita, se for justa, se for cristã, as mesmas pedras se porão de vossa parte, e quererá Deus que não sejam necessárias pedras nem pedreiras (VIEIRA [1653], 2008a, p. 116).

Vê-se, claramente, nas argumentações do jesuíta, o afloramento de uma das suas facetas: o Vieira jurista. 0 discurso do jesuíta se

17 É preciso destacarmos que não estamos afirmando que o Padre Antônio Vieira tenha sido um advogado ou juiz formado, atuando no mundo jurídico. Mas não se pode negar seu conhecimento em Direito Canônico. A nossa intenção é tão-somente demonstrar o domínio e o uso do discurso jurídico para cumprir os seus objetivos na Colônia. constitui na sua relação com os outros ${ }^{18}$, "as palavras dos outros introduzem sua própria expressividade, seu tom valorativo, que assimilamos, reestruturamos, modificamos" (BAKHTIN, 1997, p. 315). Na perspectiva bakhtiniana, fica evidente que a busca de sentido do discurso se dá na constante continuidade, na análise de elos múltiplos entre a atividade de linguagem, suas motivações, e determinações, visto que é um processo histórico de constituição das significações.

Foi a necessidade de incorporar-se ao jurista que levou Vieira a desenvolver, através de seu discurso, a face do jurista em defesa dos índios do Maranhão, tecendo uma defesa situacional aos maus tratos sofridos pelos aborígenes durante a colonização. Mas, compreendendo a importância de não desagradar aos colonos enquanto os criticava, Vieira constrói categorias e imagens dos cativeiros, dividindo-os em lícitos e ilícitos, utilizando nomenclaturas jurídicas, que reforcem a imagem do jurista em ação. Nesse percurso, podemos buscar pontos (sinais) para a constituição do imaginário social de uma determinada sociedade em uma determinada época. No Maranhão colonial do século XVII, poucos eram os profissionais do reino que se dispunham aos ofícios da justiça. Por conseguinte, Vieira dispunha de um público leigo ao seu discurso jurídico durante os seus sermões.

O jesuíta propõe, como jurista, a defesa dos cativeiros lícitos, como podemos observar nesta pregação: "Não é minha tenção que não haja escravos, antes procurei (...)

18 Quando nos referimos aos "outros" nos discursos de Vieira, não nos limitamos somente a indicação dos fazendeiros contra os quais lutou intensivamente, mas também a todos os discursos assimilados pelo sujeito Antônio Vieira ao longo de sua vida e que contribuíram para a construção dos seus discursos individuais (que são sempre individuais e coletivos, histórica e socialmente, conforme afirma Bakhtin (1997). 
que se fizesse (...) [o] cativeiro lícito"(VIEIRA [1653], 2008a, p. 116). Podemos pensar que a criação do cativeiro lícito foi uma forma de conciliar interesses, uma concessão de Vieira para amenizar os problemas que tinha com os colonos no Maranhão. Assim, classifica as populações que tinham a possibilidade de serem escravizadas no Maranhão em três grupos:1 - "os escravos que já estão na cidade"(VIEIRA [1653], 2008a, p. 114), que têm o direito de escolher se continuam a trabalhar ou não; 2 - "os que vivem nas aldeias de El-Rei como livres"(VIEIRA [1653], 2008a, p. 114) e 3 - os que "vivem nos sertões"(VIEIRA [1653], 2008a, p. 114), de que só poderiam ser trazidos aqueles que estivessem presos em tribos inimigas e para serem mortos, o que justificaria a escravidão.

Na quinta parte do sermão, segunda da confirmação, o jesuíta traz a seguinte indagação: "Não será melhor perder índios por serviços de Deus, que perdê-los por castigo de Deus?" (VIEIRA (1653), 2008a, p. 115), argumentando que quem se não contentar e não se satisfizer disto, uma das duas é: ou não é cristão, ou não tem entendimento. 0 jogo ideológico do padre não abre mão de colocar Deus no centro do debate.

Esta postura, Vieira já defendia em missiva escrita ao padre Francisco de Morais, em 6 de Maio de 1653 (VIEIRA, 2008, p. 235): "[...] nenhuma cousa faço que não seja com Deus, por Deus e para Deus; e para estar na bem-aventurança só me falta o vê-Lo, que seria maior gosto, mas não maior felicidade" (idem).

Voltando ao sermão, o jesuíta apresenta os males que anunciou: "O mal é um só, que será haverem alguns particulares de perder alguns índios, que eu vos prometo, que sejam mui poucos" (idem). Sobre esta questão corrobora Neves (1997): “O plano jesuítico que não quer ser assim adjetivado) oferecese como um bom negócio. Vieira pondera em termos quase 'mercantis', em sua expressão vocabular mesma, o que o proposto trará de positivo. Ganhar-se-á em que haverá poucas perdas de índios" (p. 187).

Quanto aos bens, o padre destacou quatro, como os mais consideráveis:

0 primeiro é ficar com as consciências tranquilas, ou seja, tirar-se-á este povo de pecado mortal; "vivereis como cristãos, confessar-vos-eis como cristãos; morrereis como cristãos, testareis de vossos bens como cristãos; enfim, ireis ao céu, não ireis ao inferno, ao menos certamente, que é triste coisa" (VIEIRA, 2008, p. 236).

O segundo plano é que os colonos retirassem de suas casas esta maldição, argumentando que não há maior maldição numa casa, nem numa família, que servir-se com suor e com sangue injusto. Tudo vai para trás, nenhuma coisa se logra, tudo leva ao diabo.

0 terceiro bem é que por este meio haverá muitos resgates, com que se tirarão muitos índios, que doutra maneira não os haverá. Vieira coloca a importância dos resgates de índios que se encontravam no sertão, em cordas, para ser comidos, que poderiam se qualificar como verdadeiramente cativos dos fazendeiros.

O quarto e último bem é que feita tal proposta, seria digno de ir às mãos de Sua Majestade, com o intuito de que Sua Majestade a aprove e a confirme. Utilizando o conceptismo, faz um jogo com as palavras afirmando que quem pede o ilícito e o injusto, merece que lhe neguem o lícito e o justo; e quem requer com consciência, com justiça e com razão, merece que lhe façam.

Este último bem, como se refere Vieira, expressa claramente a proximidade do jesuíta com o Rei D. João IV, visto que o missio- 
nário, além de representar os interesses da Ordem (Companhia de Jesus), representava também os interesses de Sua Majestade.

Percebemos aqui a intenção de Vieira em apaziguar os ânimos dos fazendeiros maranhenses colocando-os em uma posição que agradasse tanto a Fé quanto o Império e, para isso, ousa citar os limites da jurisdição do Rei, mesmo contra os índios: "El-Rei poderá mandar que os cativos sejam livres; mas que os livres sejam cativos, não chega lá sua jurisdição. Se tal proposta fosse ao reino, as pedras da rua se haviam de levantar contra os homens do Maranhão" (VIEIRA (1653), 2008a, p. 116).

O sermão foi pregado no dia 2 de março de 1653, e Vieira termina exortando os cristãos do Maranhão para que abandonassem procedimentos errados e buscassem primeiro o Reino de Deus, devendo, portanto, libertar os índios mantidos em cativeiro. Ele retoma a ideia do início sobre as tentações de Cristo para fazer admirável desfecho: "Morra o demônio, morram suas tentações, morra o pecado, morra o inferno, morra a ambição, morra o interesse; viva só o serviço de Deus, viva a Fé [...]"(VIEIRA [1653], 2008a, p. 118). Em carta de 22 de maio ao provincial, o jesuíta parece ter sido ouvido pelos fazendeiros do Maranhão e ficou a impressão de que as suas imprecações de fato calaram fundo nas almas dos ouvintes. Mas tudo era uma questão de tempo para que voltassem os problemas.

Na sexta e última parte do sermão, a peroração, Padre Vieira enfatiza que só por esse caminho - toda a proposta que vimos nas partes anteriores - os fazendeiros poderiam sentir-se com a consciência tranquila e poderiam se salvar.

A peroração deste sermão se encerra quando o jesuíta invoca o rei dos reis: "Senhor Jesus, este é o ânimo, e esta é a resolu- ção, com que estão de hoje por diante estes vossos tão fiéis católicos" (VIEIRA (1653), 2008a, p. 118), afirmando que

[...] não há ninguém aqui que queira outro serviço mais do que servi-vos; ninguém há que queira conveniência mais do que amarvos; ninguém há que tenha outra ambição, mais que de estar eternamente obediente e rendido a vossos pés (VIEIRA (1653), 2008a, p. 118).

Esta conclusão de Vieira, em relação ao sermão, ratifica o plano de tentar conscientizar os fazendeiros da sua responsabilidade com a terra (colônia), o índio e a coroa, denominando-os de "vossos tão fiéis católicos". Os elementos alegóricos "Deus" e "demônio" conferem agudeza ao antagonismo pregado pelo padre, no intuito de demonstrar aos colonos o peso do perdão e do pecado, conforme as suas escolhas.

0 discurso de Vieira equivale a uma balança que pondera o bem e o mal e aponta as consequências de um e de outro, pois quanto mais os fazendeiros fizerem o mal (escravizando e maltratando os índios), mais castigados serão pela ira de Deus.

Até a chegada de Vieira, os jesuítas que se estabeleceram no Maranhão e Grão-Pará, desde 1615, "não estiveram encarregados oficialmente da administração dos índios, ocuparam-se apenas em os catequisar (sic) nas Aldeias que visitavam, e na defesa moral delas em casos particulares" (COELHO NETT0, 1985).

Parece-nos que existia simplesmente uma restrição - dos jesuítas que antecederam Vieira - ao cumprimento de suas obrigações missionárias, ao contrário, do exercício missionário deste, que faz desde a sua chegada ao Maranhão um jogo ideológico, no sentido bakhtiniano12, que se constrói pela "articulação das leis de Deus e das leis do rei" (NEVES, 2004), uma peculiaridade 
do discurso vieiriano, que se flexibiliza em um sujeito plural e misto: missionário jesuíta (religioso), diplomata (político), escritor (literário), orador, entre outros atributos.

Notamos que Vieira tinha que lidar com questões de ordens superiores que o colocavam em questões complexas para defender interesses em comum, tais como, o projeto das missões, cujo êxito e sucesso dependia dos esforços do jesuíta Superior, ele próprio, e os interesses da Coroa, visto que como braço direito do Rei era um dos grandes representantes do Império também.

No entanto, além desses dois papéis sociais que exercia com empenho na colônia, Vieira possuía mais uma atuação que lhe custava caro na sua participação social no Maranhão do século XVII: a imagem do herói/justiceiro/guerreiro. 0 problema é que essa imagem depende do ponto de vista de quem participa dessa justiça. Para a Coroa e a Companhia de Jesus, Vieira fazia jus a este papel.

Como já dissemos anteriormente, utilizamos como referencial teórico para compreender estas faces do jesuíta a teoria bakhtiniana do discurso. Falar sobre o Padre Antônio Vieira e suas diversas facetas não é tarefa fácil, ampliar a compreensão do sujeito Vieira a partir de seu imaginário social no Maranhão do século XVII é tarefa difícil quanto buscamos compreender os outros existentes em seus discursos.

Quando optamos pelo título do capítulo "Vieira do Maranhão" em vez de "Vieira no Maranhão", entendemos que o sermões de Vieira proferidos quando esteve no Maranhão possuem múltiplas facetas, mas há uma que se destaca mais que as outras: a imagem do soberano/justiceiro, que surge como imagem recorrente na imaginação social do jesuíta ao construir os seus sermões no Maranhão.
De certa forma, cabe no imaginário ao soberano uma tríplice função: jurídico-política (o juiz), religiosa (o mago) e militar (o guerreiro). Dada a autoridade conferida pelo Rei a Vieira, não é de estranhar o isomorfismo da imagem do padre com a imagem do soberano. Quantas vezes o mesmo precisa desempenhar em missão as três funções simultaneamente, ora é quem julga, ora é quem encanta, ora é quem luta. É a partir dessas funções que entendemos que a imagem do soberano é símbolo do arquétipo do herói, típico do Regime Diurno da imagem, de estrutura heroica ou esquizomórfi$\mathrm{ca}^{19}$, conforme encontramos na classificação isotópica das imagens de Gilbert Durand (1997).

Enfim, não pretendemos afirmar que Vieira exercia um cargo jurídico ou advogava pela Companhia de Jesus, mas percebemos em seus discursos os aspectos de um discurso jurídico, que sem dúvida, na formação do jesuíta, era fortemente respaldado no Direito Canônico e defendia antes os interesses da Companhia e da Coroa. Outro fator importante é verificar até que ponto tais discursos influenciaram diretamente na sociedade maranhense da época, os seus impactos, rupturas e continuidades.

Na perspectiva bakhtiniana, a busca de sentido do discurso se dá na constante continuidade, na análise de elos múltiplos entre a atividade de linguagem, suas motivações, e determinações, visto que há um processo histórico de constituição das significações e,

19 “[...] segundo G. Durand, só existem três soluções fundamentais de defesa, três maneiras de eufemizar a morte, três maneiras básicas de vencê-la: são as três estruturas do imaginário [...] Durand percebeu que as imagens provenientes das diversas culturas se dividem em Imagens Diurnas e em Imagens Noturnas, e que esta bipartição compreende uma tripartição em estruturas, que são a "heróica", a "mística e a" sintética" (ROCHA PITTA, 2004, p. 8). 
neste percurso, podemos buscar pontos (sinais) para a constituição do imaginário social de uma determinada sociedade em uma certa época.

Quando trazemos esta discussão para análise dos sermões de Vieira, encontramos um complexo de possibilidades que determinam o objeto de estudo deste trabalho, ao passo que, quanto mais tentamos nos aproximar deste, mais nos sentimos distantes de sua apreensão, visto que se torna essencial o distanciamento para olharmos, por diferentes ângulos, a problemática em foco.

Foi com este posicionamento teórico, diante do discurso, que tivemos a intenção de percorrer, na análise do Sermão da Primeira Dominga da Quaresma ou das Tentações (1653), um caminho pelo "labirinto" da imaginação discursiva do Padre Antônio Vieira no Maranhão seiscentista a fim de perceber a constituição simbólica de um imaginário social do jesuíta.

Justamente, por entendermos ser um labirinto, são muitas as possibilidades de análise do imaginário social do jesuíta para percorrer, escolhemos o nosso caminho à luz das teorias do imaginário social jesuítico desenvolvido por Luiz Felipe Baêta Neves (2003), da teoria do imaginário de Gilbert Durand (1997) e da análise do discurso de Mikhail Bakhtin (1997) e apontamos as imagens que entendemos mais visíveis nas práticas e relações sociais constituídas pelo jesuíta no Maranhão do século XVII.

Assim, além das imagens plurais e mistas já conhecidas do padra Antônio Vieira, missionário jesuíta (religioso), diplomata (político), escritor (literário), orador, entendemos que no Maranhão uma imagem se sobressai: a imagem do soberano/justiceiro, que surge como imagem recorrente na imaginação social do jesuíta ao construir os seus sermões no Maranhão.
Essa imagem representa, de maneira geral, a constituição da sociedade maranhense da época, uma sociedade eivada de vícios que necessitava urgentemente de intervenção heroica para inverter este quadro negativo. Ela representa a forma como o Padre Antônio Vieira enxergava essa sociedade e, de maneira particular, a imaginação social do jesuíta em suas práticas sociais. É por isso, que percebemos, nas imagens que afloraram de seus sermões, um predomínio do esquema esquizomórfico ou heroico do imaginário do justiceiro.

\section{Considerações finais}

O Padre Antônio Vieira deixou-nos uma grande contribuição através de suas cartas, seus sermões e profecias. Era conhecido, no século XVII, por sua atuação política e religiosa no Brasil e em Portugal, por sua produção textual complexa e laboriosa e por sua influência na vida cultural e literária em outros países.

Esta pesquisa trouxe-nos uma grande contribuição em termos de aprendizado científico.

Fizemos, na primeira seção, uma exposição das diversas faces do Padre Antônio Vieira, sob uma perspectiva histórica de seus sermões, situando esse sujeito - homem, padre - em sua multiplicidade de atividades profissionais. Trabalhar a imaginação social jesuítica do Padre Antônio Vieira, foi uma peleja do começo ao fim, tamanha a complexidade de análise do objeto de estudo. Deparamo-nos com múltiplos Vieiras, sem sustentarmos esta complexidade em detrimento do uno (Vieira em si mesmo), autêntico, único, ou mono.

Na segunda seção, apresentamos este sujeito numa concepção dialógica bakhtiniana, principalmente, na percepção do 
olhar do sujeito Padre Antônio Vieira na construção de sermões. De fato, a multiplicidade dos seus trabalhos, em sua quase totalidade, não decorre de uma concepção de escola medieval ou de imitação de modelos, porém, de existência multiplicada em atividades diversificadas e das múltiplas facetas que a sua alma angustiada apresentava ao mundo. É difícil perceber se o jesuíta escrevia mais para si próprio ou para o leitor, mas com seu bom senso, era capaz de diagnosticar com perspicácia os males que seu país enfrentava. Tinha também coragem suficiente para receitar os remédios que lhe pareciam apropriados, mas que, por contrariarem os interesses de grupos poderosos, quase nunca eram bem recebidos (BESSELAAR, 2002, p. 33).

$\mathrm{Na}$ última seção, traçamos uma análise desses múltiplos sujeitos e olhares a partir do Sermão da Primeira Dominga da Quaresma à luz da noção ideológica de sujeito de Mikhail Bakhtin (1997), das noções do imaginário de Gilbert Durand (1997) e das teorias sobre o imaginário social jesuítico do antropólogo e pesquisador Luiz Felipe Baêta Neves (2003), entre outros grandes teóricos.

No Sermão da Primeira Dominga da Quaresma, vimos a preocupação do jesuíta com a defesa dos índios do Maranhão, tecendo uma defesa situacional aos maus tratos sofridos pelos aborígenes durante a colonização. Fizemos discussões sobre o corpo e alma, demonstrando o quanto estas diferenças eram extremamente importantes para os jesuítas no processo de catequização dos índios.

Apresentamos as diversas partes que compõe o sermão comas suas descrições e características, buscando destacar os discursos e as intenções do jesuíta. Não só explicar os planos ardilosos do diabo, mas ain- da dar ao público o verdadeiro significado do valor de uma alma, era o grande objetivo do Padre Antônio Vieira neste sermão. 0 uso do jogo contraditório entre corpo e alma permitia ao jesuíta convencê-los de que suas práticas gananciosas eram ilícitas e pecaminosas à medida que não se preocupavam de nenhuma forma com a escravização desenfreada dos índios e a exploração de sua mão de obra, mesmo mediante as sanções dos jesuítas e da Coroa ou ainda que isto representasse a condenação de suas almas.

Após descrevermos as principais funções desenvolvidas pelo jesuíta, jurídico-política (o juiz), religiosa (o mago) e militar (o guerreiro), Vieira se destaca, no imaginário, como soberano/justiceiro, aquele que julga, que encanta, que luta, função típica do soberano, símbolo do arquétipo do herói, do Regime Diurno da imagem, de estrutura heroica ou esquizomórfica, segundo a classificação isotópica das imagens de Gilbert Durand (1997).

Enfim, concluímos que, no Maranhão, o Padre Antônio Vieira desempenha um papel muito ativo nos conflitos entre jesuítas e colonos, como paladino dos direitos humanos, a propósito da exploração dos indígenas. Apesar dos inúmeros trabalhos já publicados sobre o jesuíta, esta pesquisa possibilitou-nos conhecer um pouco mais, sob a ótica do imaginário, a produção sermonística de Vieira, as imagens mais recorrentes em sua produção, sua capacidade criativa e imaginária, sua habilidade retórica e o seu imaginário social jesuítico no Maranhão do século XVII.

\section{Referências}

BACHELARD, Gaston. A Poética do Espaço. São Paulo: Martins Fontes, 1998.

BAKHTIN, Mikhail. Estética da Criação Verbal. São Paulo: Martins Fontes, 1997. 
BESSELAAR, José Van Den. Antônio Vieira: profecia e polêmica. Rio de Janeiro: EdUERJ, 2002.

BOSI, Alfredo. História concisa da Literatura Brasileira. São Paulo: Cultrix, 2001.

BRANDÃO, Jacyntho José Lins. Presença maranhense na literatura nacional. São Luís: UFMA / SIOGE, 1979, (Prêmio Universidade Federal do Maranhão - 1976).

CARVAlHO, Júlio. 0 Tecelão e o Tecido. Rio de Janeiro: EdUERJ, 2000.

CASSIRER, Ernst. Linguagem e Mito. (Tradução: J. Guinsburg e Miriam Schnaiderman). São Paulo: Editora Perspectiva, 2006.

CHACON, Vamireh. A Grande Ibéria. São Paulo: Editora UNESP; Brasília: Paralelo 15,

2005. COELHO NETTO, Eloy. Geo-história do Maranhão. São Luís: SIOGE, 1985.

DURAND, Gilbert. As Estruturas Antropológicas do Imaginário. São Paulo: Martins Fontes, 1997.

A imaginação simbólica. São Paulo: Cultrix, Editora da Universidade de São Paulo, 1988.

ELIADE, Mircea. Imagens e símbolos: ensaio sobre o simbolismo mágico-religioso. São Paulo: Martins Fontes, 2002.

JUNG, Carl Gustav. 0 homem e seus símbolos. 6 ${ }^{\mathrm{a}}$ Ed. Rio de Janeiro: Nova Fronteira, 1996.

LAROUSSE. Dicionário da Língua Portuguesa. São Paulo: Ática, 2011.

MORAES, Jomar. Apontamentos de Literatura Maranhense. $3^{\text {a }}$ ed. São Luís: SIOGE (Serviço de Imprensa e Obras Gráficas do Estado), 1979.

NEVES, Luiz Felipe Baêta. Terrena cidade celeste: imaginação social jesuítica e Inquisição. Rio de Janeiro: Atlântica, 2003.

.Transcendência, poder e cotidiano: as cartas de missionário do Padre An- tônio Vieira. Rio de Janeiro: Atlântica Editora; EdUERJ, 2004. (Coleção Brasilis)

0 Combate dos Soldados de Cristo na Terra dos Papagaios: colonialismo e repressão cultural. Rio de Janeiro: Forense-Universitária, 1978.

Vieira e a Imaginação Social Jesuítica: Maranhão e Grão-Pará no séc. XVII. Rio de Janeiro: Topbooks, 1997.

OLIVEIRA, Ana Lúcia M. de (org.). Antônio Vieira: 400 anos. Rio de Janeiro: EDUERJ, 2011.

PELOSO, Silvano. Antônio Vieira e o Império Universal: a Clavis Prophetarum e os documentos inquisitoriais. Rio de Janeiro: De Letras, 2007.

RIBEIRO, Luis Filipe. Conceito de Linguagem em Bakhtin. In: Revista Brasil. Disponível em URL: http://revistabrasil.org/revista/artigos/ crise.htm. Capturado em 19/10/2011.

ROCHA PITTA, Danielle Perin. Imaginário, Cultura e Comunicação. Revista Labirinto. Porto Velho: Fund. Univ. Fed. De Rondônia, Ano IV, № 6, 2004.

SOUZA, José Coelho. Os jesuítas no Maranhão. São Luís: Fundação Cultural do Maranhão, 1977.

VIEIRA, Antônio (organização e notas de João Lúcio de Azevedo; prefácio de Alcir Pécora). Cartas. Volume I - São Paulo: Globo, 2008.

. Sermão da Primeira Dominga da Quaresma (1653). In: Sermões. (Revisão de adaptação de Frederico Ozanam Pessoa de Barros; supervisão de Padre Antônio Charbel, S.D.B. e de A. Della Nina; introdução e supervisão de Luiz Felipe Baêta Neves). Erechim: EDELBRA, 1998a. (Volume XI)

Essencial Padre Antônio Vieira.

(Organização e introdução de Alfredo Bosi). São Paulo: Penguin Classics Companhia das Letras, 2011.

Recebido em: 24/10/2019 Aceito em: 13/02/2020 